\title{
PROFIL ARGUMENTASI MAHASISWA DALAM MELAKUKAN PEMBUKTIAN PADA TOPIK ANALSISIS KOMPLEKS
}

\author{
Hapipi, Syahrul Azmi, M. Turmuzi \\ Department of Mathematics Education \\ Faculty of Teacher Training and Education \\ Mataram University \\ hapipimath@unram.ac.id
}

\begin{abstract}
Abstrak.Tulisan ini merupakan bagian dari penelitian yang dimaksudkan untuk mendapatkan gambaran tentang profil argumentasi mahasiswa Matematika FKIP Unram dalam melakukan pembuktian matematik.Tulisan ini hanya fokus pada data responden dalam mengembangkan argumen pembuktian pada topik Analisis Kompleks. Hasil analisis menunjukkan bahwa mahasiswa masih mengalami kesulitan dalam menyajikan argumen pembuktian yang valid. Dari 62 responden dalam membuktikan dua pernyataan matematik, diketahui bahwa hanya $24.2 \%$ argumen valid, sedangkan sisanya tidak valid, bahkan $14.5 \%$ diantaranya tidak menjawab. Kelemahan argumen yang dikembangkan diakibatkan oleh kombinasi antara tidak tepatnya Data maupun Warrant yang digunakan.
\end{abstract}

Kata Kunci:Argumen, Pembuktian, Model Toulmin.

\section{ARGUMENTATION PROFILE OF MATHEMATICS STUDENT ON PROVING COMPLEX ANALYSIS TOPIC}

\begin{abstract}
This article is part of research on analysis of argumentation profile of mathematics student on proving process. Data of the article is based on argument provided by students on Analysis Complex topic. The research result shows that majority of argument proposed is categorized as invalid argument. It is due to lack of data and warrant was being used. Out of 62 respondents working with two mathematics propositions, $24.2 \%$ valid and $14.5 \%$ failed in providing any arguments.
\end{abstract}

Keywords: Argument, Proof, Toulmin's Model. 
Mathematics and Educations Journal

Volume 1 Nomor 1, Juni 2019

\section{PENDAHULUAN}

Matematika adalah cabang ilmu yang mensyaratkan pembuktian sangat ketat pada setiap pernyataannya.Oleh karena itu, Ufer, S., Heinze, A. and Reiss, K. [1] menyebut bahwa bukti maupun pembuktian merupakan fondasi utama terbangunnya hasanah ilmu matematika.Bahkan, Ubuz dalam [2] menegaskan bahwa argumentasi dan pembuktian adalah elemen yang sangat penting dalam matematika.

Argumentasi adalah kegiatan yang berupa aktivitas membuat alasan, melakukan induksi, maupun menarik kesimpulan [3].Vincent, J.; Chick, H.; McCrae, B.,[4]juga menegaskan bahwa argumentasi dalam matematika dapat dipandang sebagai proses mengembangkan dan menghubungkan gagasan matematik secara logis. Sedangkan argument adalah kumpulan pernyataan matematis yang digunakan untuk memberikan keyakinan terhadap suatu claim. Adapun "bukti", sebagai hasil dari proses pembuktian (Godel dalam[5]), memuat serangkaian gagasan yang dapat diterima oleh pikiran rasional. Oleh karena itu, bukti dalam matematika adalah suatu argument yang dihasilkan dari proses argumentasi.Dengan demikian argumentasi merupakan aktivitas yang secara bersamaan muncul pada setiap aktivitas pembuktian. Bahkan, ia memerankan peran sangat penting dalam proses pembuktian.

Penguatan kemampuan dalam melakukan pembuktian, merupakan salah satu isu utama pembelajaran matematika.Hal ini disebabkan oleh kenyataan bahwa kompetensi dalam melakukan pembuktian pernyataan matematis adalah salah satu karakteristik utama mahasiswa matematika.Namun demikian, kajian pada bagaimana meningkatkan kemampuan siswa dalam melakukan pembuktian memang masih sangat sedikit [6].Pada saat yang bersamaan pembuktian merupakan topik yang sulit untuk dipelajari dan juga dibelajarkan [7].Padahal, kemampuan berargumentasi termasuk kemampuan dalam melakukan justifikasi maupun penyangkalan merupakan kemampuan yang harus muncul dalam setiap proses pembuktian. Kemampuan semacam inilah, lebih familiar disebut kemampuan berfikir tingkat tinggi (higher order thinking skill)[8] yang sangat dibutuhkan mahasiswa.

Lebih jauh, karena pada setiap proses pembuktian selalu melibatkan proses berpikir dan berargumentasi, maka secara langsung kemampuan penalaran santifik (scientific reasoning) serta argumentasi saintifik (scientific argumentation) 
Mathematics and Educations Journal

Volume 1 Nomor 1, Juni 2019

siswa/mahasiswa akan semakin terasah. Dua kemampuan inilah [9] yang sangat dibutuhkan setiap orang di abad ke-21 ini.

Pada saat yang bersamaan, kajian yang lebih utuh terhadap isu ini belum banyak dilakukan.Padahal upaya penguatan kemampuan mahasiswa dalam membuat argumen, termasuk yang berkaitan dengan aktivitas pembuktian sangat penting dilakukan.Untuk mewujudkannya, maka terlebih dahulu harus diketahui bagaimana profil kemampuan mahasiswa dalam hal ini. Pemahaman yang utuh atas kemampuan mahasiswa dalam menyatakan argumen pada pembuktian matematis akan mempermudah perumusan bentuk intervensi yang diperlukan dalam proses pembelajaran. Oleh karena itu, pemetaan yang lebih komprehensif terhadap kemampuan berargumentasi mahasiswa penting dilakukan.

\section{METODE PENELITIAN}

Data yang disajikan pada artikel ini merupakan sebagian dari data penelitian yang bertujuan untuk mendapatkan gambaran tentang profil argumentasi mahasiswa matematika dalam melakukan pembuktian matematis.Penelitian tersebut dilakukan pada mahasiswa matematika FKIP Universitas Mataram yang ditentukan dengan teknik proportionate stratified random sampling untuk merepresentasi perbedaan kelompok dan jenjang mahasiswa yang sedang mengambil kuliah aljabar, analisis, dan geometri. Sugiyono [10]menyatakan bahwa teknik pengambilan sampel ini digunakan apabila populasi mempunyai anggota/unsur yang tidak homogen dan berstrata secara proporsional.Artikel ini dibuat untuk merepresentasi matakuliah analisis, khususnya Analisis Kompleks.Data berasal dari 62 jawaban mahasiswa, dari 127 total mahasiswa yang mengikuti matakuliah Analsisis Kompleks.Adapun instrumen penelitian berupa soal pembuktian yang selanjutnya dianalisis dengan mengacu pada struktur layout Argumen Toulmin. 
Mathematics and Educations Journal

Volume 1 Nomor 1, Juni 2019

\section{HASIL DAN PEMBAHASAN}

Penelitian ini dimaksudkan unutk memperoleh gambaran tentang profil argumentasi mahasiswa dalam melakukan pembuktian pernyataan matematika.Profil argumentasi adalah gambaranstruktur/unsur argumen serta keterkaitan struktur tersebut dalam membentuk suatu argumen.Bagi Toulmin [11], suatu argumen dibangun oleh sedikitnya tiga unsur utama yaitu Claim, Data, dan Warrant. Model Toulmin ini tepat digunakan untuk menganalisis pembuktian matematis karena kesamaan strukturnya dengan argumen model Toulmin [12]. Model Toulmin ini juga telah digunakan secara luas dalam menganalisis penalaran matematika [13].

Pada artikel ini, disajikan profil argumentasi mahasiswa dalam melakukan pembuktian pernyataan yang berkaitan dengan topik Analisis Kompleks.Data profil argumentasi diperoleh dari analisis terhadap jawaban 62 orang mahasiswa pada dua soal pembuktian yang diberikan.

Soall:

Diberikan $Z_{i} \in \square, i \in\{1,2,3,4\}$.

Buktikan bahwa jika $\left|Z_{3}\right| \neq\left|Z_{4}\right|$ maka $\left|\frac{Z_{1}-Z_{2}}{Z_{3}-Z_{4}}\right| \leq \frac{\left|Z_{1}\right|+\left|Z_{2}\right|}{|| Z_{3}|-| Z_{4} \mid}$

\section{Soal 2:}

Misalkan $Z \in \square$.

Tunjukkan bahwa $Z \bar{Z}<[2 \operatorname{Re} Z]^{2}+[2 \operatorname{Im} Z]^{2}$.

Dalam perpsektif Toulmin[14], Claim atau kesimpulan adalah sesuatu yang mau dibuktikan/dibangun kebenarnnya.Sedangkan Data adalah sesuatu/fakta/informasi yang menjadi fondasi untuk membangun atau untuk mendukung kebenaran dari Claim tersebut.Adapun Warrant adalah metode berfikir yang menghubungkan antara Data dan Claim secara logis.Ketiga unsur tersebut diilustrasikan pada gambar 1 berikut.

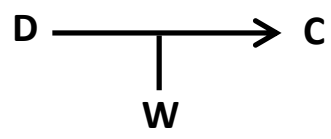

Gambar 1. Layout Argumen 
Mathematics and Educations Journal

Volume 1 Nomor 1, Juni 2019

Secara sederhana, gambar 1. di atas dapat dibahasakan sebagai Claim (C) suatu argument disebut sahih apabila didasarkan dan didukung oleh data (D) yang kuat/valid, serta disimpulkan dengan metode berfikir (W) yang benar. Warrant merupakan jaminan bahwa eksistensi Data memang dapat mendukung Claim.

Selain tiga unsur utama tersebut, Toulmin [15] juga menyebutkan bahwa suatu argumen mengandung derajat kekuatan yang dapat terlihat dari aspek Backing, Quilifier, dan Rebuttal yang melekat padanya.Hanya saja, ketiga aspek tambahan ini merupakan pendukung bagi tiga unsur yang pertama. Pada artikel ini, hanya akan disajikan dalam tiga unsur yang pertama.

\section{Profil argumenatsi secara umum}

Berikut ini gambaran profil argumentasi mahasiswa dalam melakukan pembuktian pernyataan matematis pada topik Analisis Kompleks.

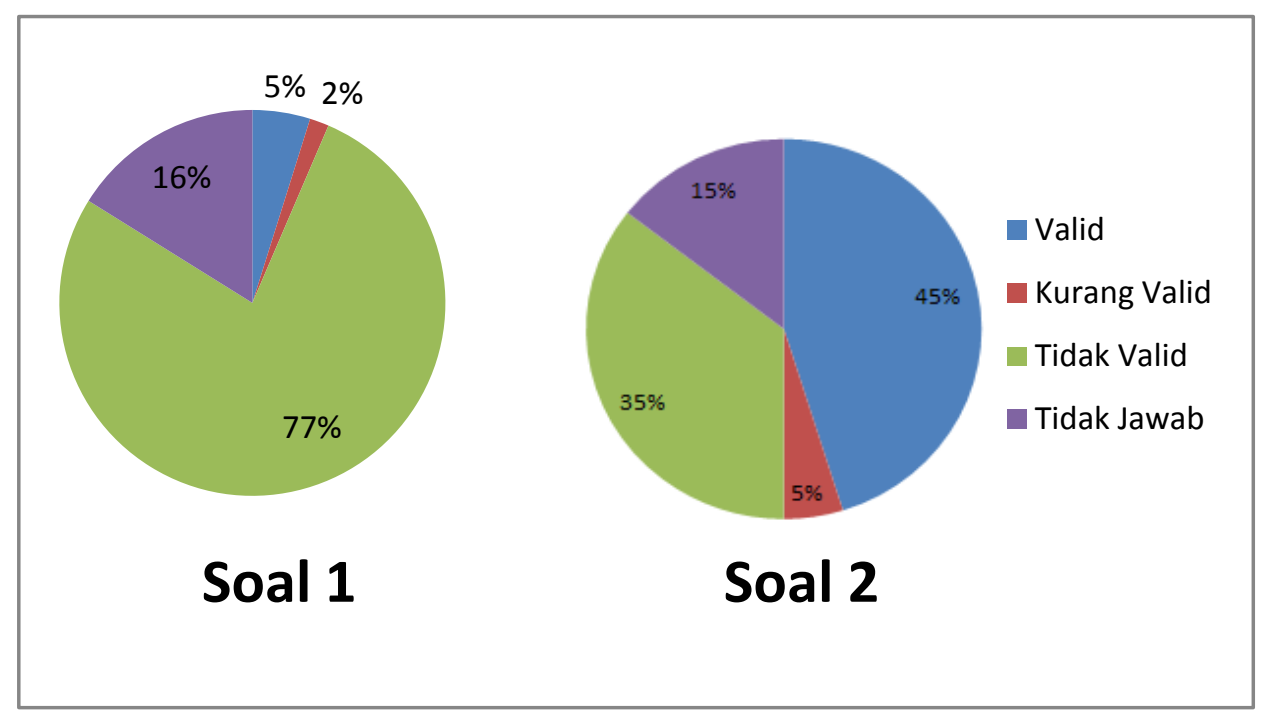

Gambar 2. Profil Argumentasi Mahasiswa dalam Pembuktian

Dari pie chart di atas terlihat bahwa secara umum, sekitar $85 \%$, responden menuliskan jawaban mereka sehingga argumen yang disampaikan bisa dianalisis.Dari hasil analisis diketahui bahwa mayoritas responden tidak menyajikan argument dengan valid.Hanya 5\% argument valid pada soal 1 dan tidak sampai 50\% argument valid untuk soal 2. 
Mathematics and Educations Journal

Volume 1 Nomor 1, Juni 2019

Kesimpulan tersebut diperolah dengan menganalisis Data, Warrant, dan Claim yang disampaikan.Perlu dicatat bahwa dalam kasus ini, permasalahan yang dibuktikan merupakan masalah yang Claim-nya sudah jelas. Artinya, pernyataan yang akan dibuktikan kebenarannya sudah diberikan. Responden tidak diminta untuk merumuskan Claim secara mandiri.Oleh karena itu, analisis difokuskan pada bagaiama Data yang disajikan mendukung kebenaran Claim, serta bagaimana kontruksi Warrant sehingga Data yang ada, mendukung Claim.

Dengan melihat Data dan Warrant yang digunakan, maka diperoleh gambaran tentang profil kekuatan argumentasi yang disajikan responden.Warrant yang tepat dengan Data yang tepat menghasilkan Claim yang valid, sedangkan Warrant dan Data yang tidak tepat menyebabkan Claim tidak valid. Adapun Data yang lemah dengan Warrant yang tepat atau Data yang tepat tetapi Warrantnya lemah dikategorisasi sebagai kurang valid.Hasil kategorisasi untuk soal 1 disajikan berikut ini.

Tabel1. Gambaran Validitas Argumen ditinjau dari kualitas Data dan Warrantnya

\begin{tabular}{lcccc} 
Warrant $\backslash$ Data & Tepat & Lemah & Salah & Tidak Relevan \\
\hline Tepat & $4.8 \%$ & $1.6 \%$ & $8.1 \%$ & $1.6 \%$ \\
\hline Lemah & - & $6.5 \%$ & $3.2 \%$ & $3.2 \%$ \\
\hline Tidak Tepat & - & $12.9 \%$ & $6.5 \%$ & $35.5 \%$ \\
\hline
\end{tabular}

Dari tabel di atas terlihat bahwa argument yang dibangun dengan Data dan Warrant yang tepat hanya 4.8\%.Sedangkan Data yang lemah tetapi Warrant yang tepat sebesar 1.6\%.Persentase terbesar (35\%) adalah Datanya tidak relevan dan dibangun dengan Warrant yang tidak tepat pula. Demikian pula ada sekitar 13\% argument yang datanya lemah dan dibangun dengan warrant yang tidak tepat. Adapun sisanya, merupakan argument dengan kombinasi data salah, data lemah, dan dibangun dengan warrant yang lemah maupun tidak tepat. 
Mathematics and Educations Journal

Volume 1 Nomor 1, Juni 2019

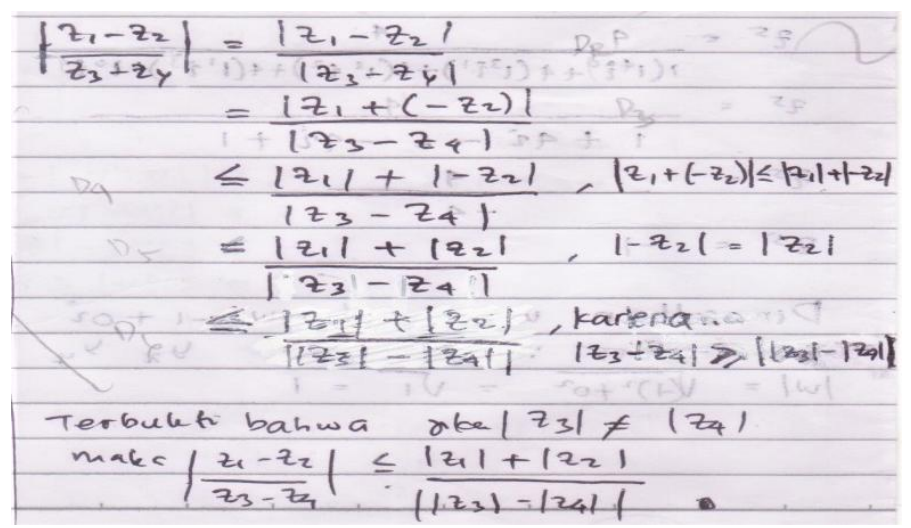

Gambar 3. Argumen dengan D dan W yang tepat

Argumen pada gambar 3tersusun dari tujuh baris pernyataan, dengan setiap baris memuat data yang tepat.Kesamaan pada baris pertama, kedua, keempat, serta ketaksamaan pada baris ketiga, dan kelima merupakan data yang benar sesuai dengan definisi dan sifat modulus bilangan kompleks.Demikian pula struktur argumen membentuk suatu rangkaian argument yang tersusun dalam silogisme."Jika baris pertama berlaku maka baris kedua berlaku, jika kedua maka ketiga, dan seterusnya, sampai pada kesimpulannya".Artinya argumen tersebut tersusun dalam struktur Warrant yang tepat. Dengan demikian, argument di atas didukung oleh Data dan Warrant yang tepat, sehingga Simpulan (C) menjadi valid.

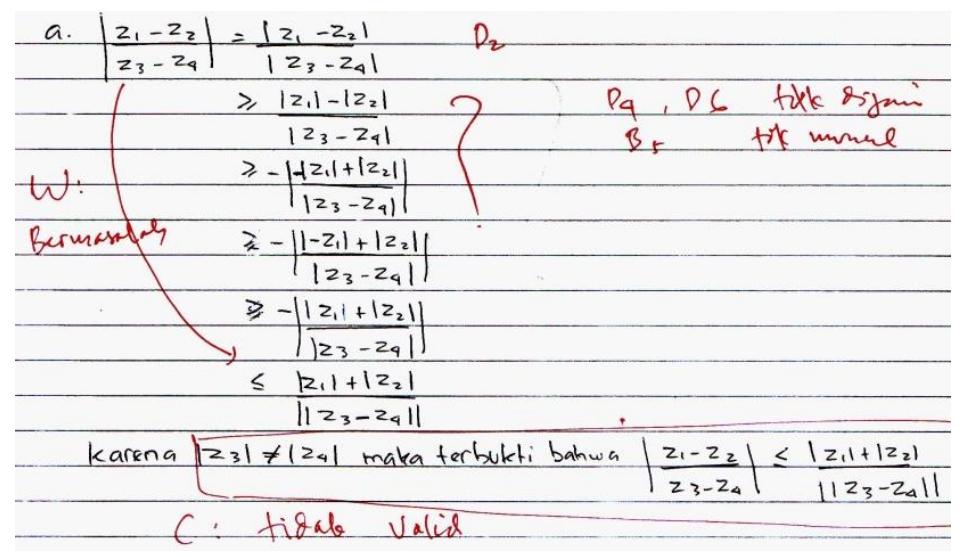

Gambar 4. Argumen dengan D Lemah dan W tidak tepat

Sedangkan pada gambar 4 di atas, terlihat bahwa argumen tidak terbangun dengan baik.Dari enam baris data yang disajikan, hanya data baris pertama yang 
Mathematics and Educations Journal

Volume 1 Nomor 1, Juni 2019

benar.Demikian pula dengan warrantnya, tidak membentuk suatu struktur berfikir yang yang dapat diterima kebenarannya.Pernyataan pada baris pertama memiliki nilai yang lebih besar disbanding pernyataan baris kedua, sampai kelima.Namun, secara tiba-tiba, kelima pernyataan tersebut nilainya lebih kecil dari pernyataan baris keenam.Kemudian disimpulkan, bahwa kebenaran claim terjustifikasi.Tentu saja, struktur argument seperti ini, tidak dapat dikategorikan sebagai suatau argument yang valid.

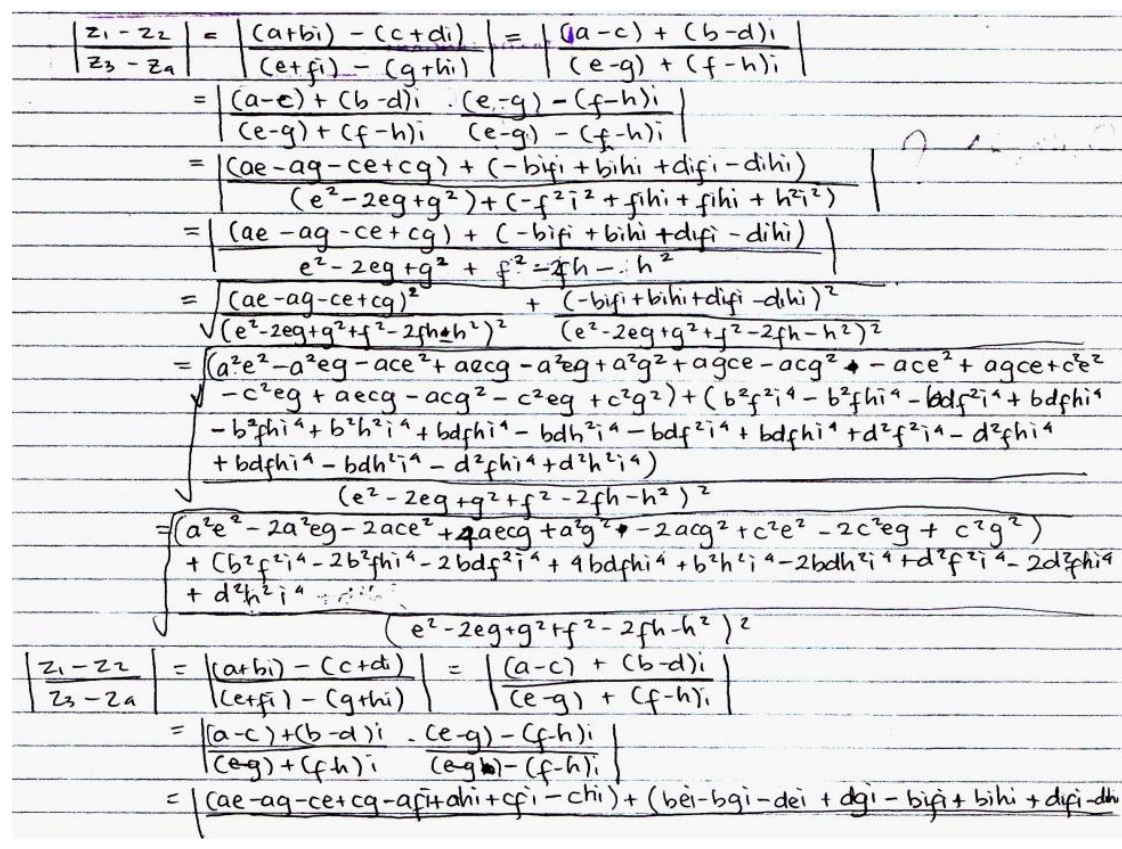

Gambar 5. Argumen dengan D tidak relevan dan W tidak tepat

Pada gambar 5, tampak bahwa data yang disajikan tidak relevan dengan claim yang hendak dibuktikan.Demikian pula pernyataan-pernyataan yang disajikan tidak membentuk suatu argument yang utuh.Oleh karena itu, warrantnya tidak tepat.

Profil argumentasi untuk soal 2 juga serupa, dimana ketidakvalidan suatu Claim disebabkan oleh data dan warrant yang disajikan kurang mendukung claim, bahkan beberapa diantaranya salah.Hanya saja, persentase argument valid untuk soal 2 ini lebih besar dibanding soal 1.Secara lebih utuh, dapat dilihat pada Tabel 2 berikut ini.

Tabel2. Gambaran Validitas Argumen ditinjau dari kualitas Data dan Warrantnya 
Mathematics and Educations Journal

Volume 1 Nomor 1, Juni 2019

\begin{tabular}{lcccc}
\hline Warrant\ Data & Tepat & Lemah & Salah & Tidak Relevan \\
\hline Tepat & $43.5 \%$ & $4.8 \%$ & $9.7 \%$ & \\
\hline Lemah & $6.5 \%$ & & $1.6 \%$ & \\
\hline Tidak Tepat & & $12.9 \%$ & $3.2 \%$ & $4.8 \%$ \\
\hline
\end{tabular}

Pada tabel 2 terlihat bahwa persentasi argument dengan data dan warrant yang valid mencapai 43.5\%. Meskipun masih di bawah 50\%, data ini jauh lebih baik dibanding data sejenis untuk soal nomor 1.Namun demikian, distribusinya juga serupa dengan data dari soal nomor 1, dimana terdapat argument dengan Data lemah tapi warrannya tepat dan sebaliknya, yaitu masing-masing $4.8 \%$ dan 6.5\%. Demikian pula, argument dengan data salah mencapai $14.5 \%$.berikut ini disajikan contoh argument dengan beberapa variasi data dan warrant.

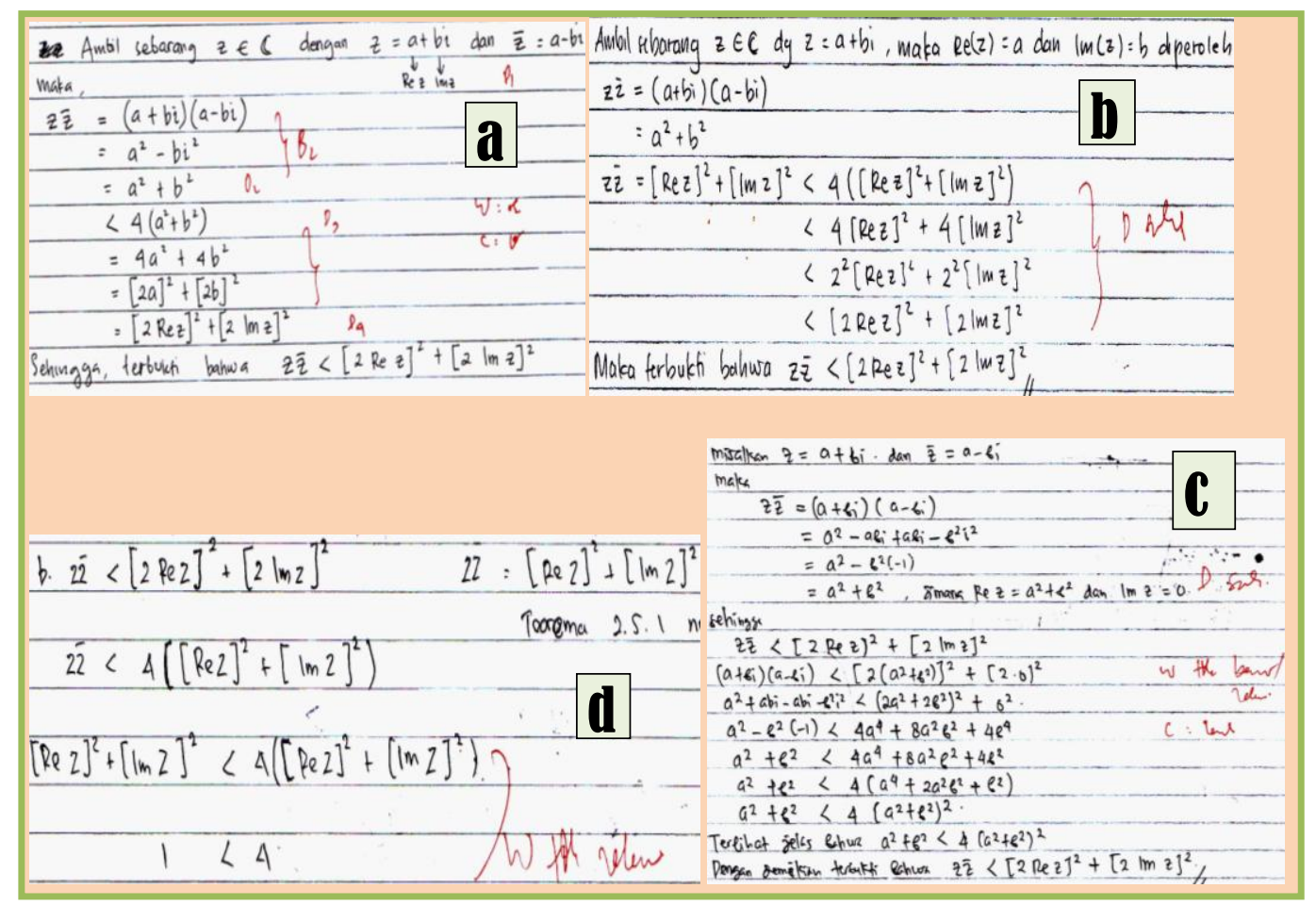

Gambar 6. Argumen dengan beberapa variasi D dan W

Gambar 6a merupakan contoh argument dengan data dan warrant yang tepat. Gambar $6 \mathrm{~b}$ merupakan argument dengan warrant tepat tetapi data salah. Sedangkan gambar $6 \mathrm{c}$ dan $6 \mathrm{~d}$ masing-masing merupakan argument dengan data lemah dan warran tidak tepat, serta data tidak relevan dan warrant tidak tepat. 
Pada gambar 6b, pernyataan baris pertama sampai dengan baris kedelapan, membentuk suatu suatu strukutur argument pembuktian yang baik.Hanya saja pernyataan baris kelima sampai baris ketujuh merupakan pernyatan yang salah dikarenakan hubungan ketaksamaan yang ada.Padahal pernyataan-pernyataan tersebut harsunyamerupakan kesamaan.Sedangkan pada gambar 6c, terlihat bahwa terjadi kesalahan struktur berfikir pada argument yang dibuat.Claimnya hendak menunjukkan bahwa ketaksamaan $Z \bar{Z}<[2 \operatorname{Re} Z]^{2}+[2 \operatorname{Im} Z]^{2}$ berlaku.Akan tetapi pembuktiannya dilakukan berangkat dari pengakuan bahwa ketaksamaan tersebut memang berlaku. Sehingga proses pembuktian tidak terjadi. Yang ada hanyalah proses penguraian. Di sinilah terjadi struktur berfikir (warrant) dalam pembuktian yang tidak tepat.

Kalau diperhatikan pola sebaran dan bentuk argument yang dikemukakan dalam pembuktian tersebut, maka secara garis besar, hal ini berkaitan dengan penguasaan mahasiswa pada konsep (basic knowledge) yang dibutuhkan dalam melakukan pembuktian, dan juga pemahaman mereka pada metode pembuktian yang benar. Hal ini sejalan dengan temuan Ufer [1] dimana $40 \%$ variasi dalam pembuktian geometri ditentukan oleh tiga hal yaitu: penguasaan konsep (basic knowledge), pemahaman tentang prosedur/metode pembuktian (procedural knowledge), dan keterampilan problem solving.

Heinze [16] juga menemukan bahwa ssiwa masih kesulitan dalam melakukan pembuktian.Bahkan oleh siswa yang memiliki prestasi tinggi.Mereka kesulitan dalam melakukan generaliasi ide saat pembuktian, sedangkan siswa dengan prestasi akademik rendah kesulitan dalam menyusun bukti serta lemahnya pemahaman prosedur dan metode pembuktian.Healy, L., andHoyles, C.[17] juga menemukan bahwa hanya $3 \%$ dari sampel yang diteliti mampu melakukan pembuktian dengan baik.Sedangkan 30\% lebih, bahkan kesulitan dalam melakukan pembuktian sederhana.Penelitian Harel, G., and Sowder, L.[18] untuk mahasiswa juga menemukan hal yang serupa.

\section{KESIMPULAN}


Mathematics and Educations Journal

Volume 1 Nomor 1, Juni 2019

Dari temuan hasil penelitian ini dapat disimpulkan bahwa kemampuan berargumentasi mahasiwa dalam melakukan pembuktian matematis masih lemah.Hal ini terlihat dari kecilnya persentase mahasiswa yang dapat menyatakan argument valid. Dari dua soal terhadap 62 mahasiswa, persentase argument pembuktian valid sekitar $24.2 \%$, sedangkan sisanya tidak valid, bahkan tidak menjawab sama sekali. Lebih jauh, tidak validnya argument pembuktian yang dikembangkan diakibatkan oleh kombinasi tidak tepatnya Data yang digunakan maupun Warrant yang diterapkan.

\section{ACKNOWLEDGMENT}

Penelitian ini berlangsung atas dukungan Fakultas Keguruan dan Ilmu Pendidikan Universitas Mataram melalui Hibah PNBP-2019.

\section{DAFTAR PUSTAKA}

[1] Ufer, S.; Heinze, A.; Reiss, K., (2008). Individual Predictors of Geometrical Proof Competence. Proceedings of the Joint Meeting of the $32^{\text {nd }}$ Conference of the International Group for Psycology of Mathematic Education, and the XX North American Chapter Vol. 1, pp. XXX-YYY. Morelia, Michoacan, Mexico.

[2] Sommerhoff, D.;Ufer, S.; Kollar, I., (2015). Research on Mathematical Argumentation: A Descriptive Review of PME Proceedings. Proceedings of $39^{\text {th }}$ Psycology of Mathematics Education Conference, Vol.4, pp.193-200. Hobart, Australia.

[3] Boero, P., 1999. Argumentation an Mathematical Proof: A Complex, Productive, Unavoidable Relationship in Mathematic and Mathematic Education.

[4] Vincent, J.; Chick, H.; McCrae, B., (2005). Argumentation Profile Charts as Tools for Analysing Students' Argumentations. Proceedings of the $29^{\text {th }}$ Conference of the International Group for the Psycology of Mathematics Education, Vol.4, pp.281-288. Melbourne.

[5] Banegas, J.A., (2003). Argumentation in Mathematics. XIIe Congres Valencia de Filosofia (E. Casaban I Moya, editor), Valencia, 1998. Translated by Miguel Gimenez $\&$ Andrew Aberdein of University of Edinburgh.

[6] Stylianides, G.J. and Stylianides, A.J., (2017). Research-Based Interventions in the Area of Proof: the Past, the Present, and the Future. Educ Stud Math, 96:119-127. Springer Science+Business Media B.V. DOI 10.1007/s10649-017-9782-3.

[7] Stylianides, A.J., (2018). Secondary Students' Proof Constructions in Mathematics: The Role of Written Versus Oral Mode of Argument Representation. Review of Education, Vol... No.... DOI:10.1002/rev3.3157. 
Mathematics and Educations Journal

Volume 1 Nomor 1, Juni 2019

[8] Marshall, J.C., and Horton, R.M., (2011). The Relationship of Teacher-Facilitated, Inquiry-Based Instruction to Students Higher-Order Thinking. School Science and Mathematics. Volume 111 (3) : 93-101.

[9] Fischer, F., Kollar, I., Ufer, S., Sodian, B., . . . Eberle, J., 2014. Scientific Reasoning and Argumentation: Advancing an Interdisciplinary Research Agenda in Education. Frontline Learning Research 5, 28-45.

[10] Sugiyono, (2008). Metode PenelitiaanPendidikan Pendekatan Kuantitatif, Kualitatif, dan $R \& D$. Alfabeta, Bandung.

[11] Toulmin, S., (2003). The Uses of Argument, Updated Edition.Cambridge University Press. Page 90.

[12] Pedemonte, B., (2007). Structural Relationship between Argumentation an Proof in Solving Open Problem in Algebra. Instituto per le Tecnologie Didattiche-CNR Genova.

[13] Barrier, Th.; Mathe, A.-C.; Durand-Guerrier, V., (2009). Argumentation and Proof: A Discussion about Toulmin's and Duval's Models. Proceeding of CERME 6, January $28^{\text {th }}$-February $1^{\text {st }} 2009$, Lyon France.

[14] Toulmin, S., (2003). The Uses of Argument, Updated Edition. Cambridge University Press. Page 90-92.

[15] Simpson, A. (2015). The Anatomy of a Mathematical Proof: Implications for Analyses with Toulmin's Scheme. Educational Studies in Mathematics., 90 (1). Pp. 1-17. https://dx.doi.org/10.1007/s10649-015-9616-0.

[16] Heinze, A., (2004). The Proving Process in Mathematics Classroom-Method and Results of a Video Study. Proceeding of the $28^{\text {th }}$ Conference of the International Group for Psychology of Mathematics Education. Vol 3 pp 41-48.

[17] Healy, L., Hoyles, C., (2000). A Study of Proof Conception in Algebra. Journal for Research in Mathematics Education, Vol. 31, No.4. pp. 396-428.

[18] Harel, G. and Sowder, L., (2003). Case Studies of Mathematics Majors' Proof Understanding, Production, and Appreciation. Canadian Journal of Science, Mathematics and Technology Education, Volume 3, 2003. 